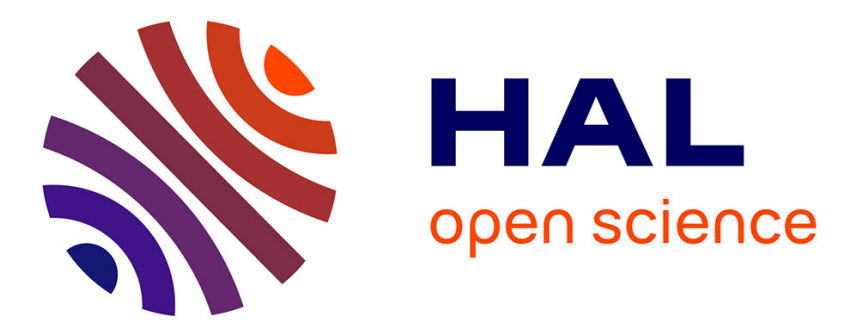

\title{
Modelling the overall effect of $\mathrm{pH}$ on the apparent heat resistance of Bacillus cereus spores
}

Olivier Couvert, Ivan Leguerinel, Pierre Mafart

\section{To cite this version:}

Olivier Couvert, Ivan Leguerinel, Pierre Mafart. Modelling the overall effect of $\mathrm{pH}$ on the apparent heat resistance of Bacillus cereus spores. International Journal of Food Microbiology, 1999, 49 (1-2), pp.57-62. 10.1016/S0168-1605(99)00052-5 . hal-00560865

\section{HAL Id: hal-00560865 \\ https://hal.univ-brest.fr/hal-00560865}

Submitted on 9 Jan 2012

HAL is a multi-disciplinary open access archive for the deposit and dissemination of scientific research documents, whether they are published or not. The documents may come from teaching and research institutions in France or abroad, or from public or private research centers.
L'archive ouverte pluridisciplinaire HAL, est destinée au dépôt et à la diffusion de documents scientifiques de niveau recherche, publiés ou non, émanant des établissements d'enseignement et de recherche français ou étrangers, des laboratoires publics ou privés. 


\section{Modelling the overall effect of $\mathrm{pH}$ on the apparent heat resistance}

\section{of Bacillus cereus spores}

\section{O. Couvert, I. Leguerinel and P. Mafart}

Laboratoire Universitaire de Microbiologie Appliquée de Quimper, Quimper,

\section{France.}

Address inquiries to: Pr Mafart, I.U.P. Innovation en Industries Alimentaires, Pôle Universitaire P. Jakez Hélias, 29000 Quimper, France.

Tel33.98.10.00.61e.mail : pierremafart@univ-brest.fr 


\section{Introduction}

Among environmental conditions that affect spore thermoresistance, $\mathrm{pH}$ is a major factor in microbial destruction. It has been recognised for several years that low $\mathrm{pH}$ values reduce spore resistance

(Alderton et al., 1976; Townsend et al., 1938; Tsuji et al., 1960). However, available information related to the quantitative effect of $\mathrm{pH}$ is scarce. Jordan and Jacobs (1948) observed a linear relationship between the D-value (decimal reduction time) of Escherichia coli and the $\mathrm{pH}$ of the heating menstruum. Davey et al., (1978) and, more recently, Mafart and Leguérinel, (1998), proposed a model to describe the combined effect of temperature and $\mathrm{pH}$ on heat resistance of spores.

These models were developed from data where D-values were estimated by recovering surviving cells at optimum conditions and, particularly, at optimal $\mathrm{pH}$ of the recovery medium. However, it is well known that counts of survival spores after a heat treatment are greatly influenced by the characteristcs of the recovery medium (temperature, $\mathrm{pH}$, water activity, composition). At non optimum recovery conditions, both a decrease in the number of viable cells capable of producing colonies and a decrease in the estimated decimal reduction time are observed. It is generally accepted that the $\mathrm{pH}$ of the recovery medium exerts a great influence on the apparent heat resistance of spores: D-values decrease as $\mathrm{pH}$ is reduced (Cook and Brown, 1965; Yokoya and York, 1965; 
Cook and Gilbert, 1968; Mallidis and Scholefield, 1986; Santos and Zarzo, 1996; Lopez et al., 1997).

This paper aims to present a simple overall model which takes into account both the effect of the $\mathrm{pH}$ of the heating menstruum and that of the recovery medium upon the observed D-value.

Assuming a "multiplicative" effect of the $\mathrm{pH}$ on the D-value, the influence of the heating menstruum $\mathrm{pH}$ can be written:

$\mathrm{D}=\mathrm{f}(\mathrm{pH}) \cdot \mathrm{D}^{*}$

where $\mathrm{D}^{*}$ is the maximum $\mathrm{D}$-value at the optimum $\mathrm{pH}$. Similarly, the effect of the recovery medium $\mathrm{pH}$ can be written:

$\mathrm{D}^{\prime}=\mathrm{f}^{\prime}(\mathrm{pH}) \cdot \mathrm{D}$

where $\mathrm{D}^{\prime}$ is the apparent decimal reduction time at $\mathrm{pH}^{\prime}(\mathrm{pH}$ of the recovery medium). The overall model is provided by combining Eqn (1) and (2):

$D^{\prime}=f(p H) . f^{\prime}\left(p H^{\prime}\right) . D^{*}$

Model (3) can be linearized by the following logarithmic transformation:

$\log \mathrm{D}^{\prime}=\log \mathrm{D}^{*}+\log \mathrm{f}(\mathrm{pH})+\log \mathrm{f}^{\prime}\left(\mathrm{pH}^{\prime}\right)$

The destruction factor $\mathrm{f}(\mathrm{pH})$ which is related to Mafart and Leguérinel's model (1998) corresponds to:

$f(p H)=10^{-\frac{\left(p H-p H^{*}\right)^{2}}{z_{p H}^{2}}}$

in which $\mathrm{pH}^{*}$ is the optimum $\mathrm{pH}$ of the heating menstruum corresponding to the maximum heat resistance. On account of the similitude of patterns which can be 
observed between curves plotting $\mathrm{D} v s \mathrm{pH}$ and $\mathrm{D}^{\prime} v s \mathrm{pH}$ respectively, and in order to keep the homogeneity of the overall model, we tested the following stress factor:

$f^{\prime}\left(p H^{\prime}\right)=10^{-\frac{\left(p H^{\prime}-p H^{* *}\right)^{2}}{z_{p H}^{\prime 2}}}$

where $\mathrm{pH}^{\prime *}$ is the optimum $\mathrm{pH}$ of the recovery medium corresponding to the maximum D' value. Then, Eqn (4) was transformed into:

$\log D^{\prime}=\log D^{*}-\frac{\left(p H-p H^{*}\right)^{2}}{z_{p H}^{2}}-\frac{\left(p H^{\prime}-p H^{\prime *}\right)^{2}}{z_{p H}^{\prime 2}}$

\section{Materials and methods}

\section{Micro-organism and spore production}

The strain of Bacillus cereus (CNRZ 110) was obtained from the Institut National de Recherche Agronomie (France). Spores were kept in distilled water at $4^{\circ} \mathrm{C}$.

Cells were precultivated at $37^{\circ} \mathrm{C}$ during $24 \mathrm{~h}$ in Brain Heart Infusion (Difco ). The preculture was used to inoculate nutritive agar plates (Biokar Diagnostics BK021) added with $\mathrm{MnSO}_{4} 40 \mathrm{mg} \mathrm{l}^{-1}$ and $\mathrm{CaCl}_{2} 100 \mathrm{mgl}^{-1}$ on the surface area. Plates were incubated at $37^{\circ} \mathrm{C}$ for 5 days. Spores were then collected by scraping the surface of the agar, suspended in sterile distilled water, and washed three times by centrifugation (10000xg for $15 \mathrm{~min}$ ) (Bioblock Scientific, model Sigma 3K30). The pellet was then suspended 
againin $5 \mathrm{ml}$ distilled water and $5 \mathrm{ml}$ ethanol. The obtained suspension was then kept at $4^{\circ} \mathrm{C}$ during 12 hours in order to eliminate vegetative non sporulated bacteria, and washed again three times by centrifugation. The final suspension (about $10^{10}$ spores $\mathrm{ml}^{-1}$ ) was finally distributed in sterile Eppendorf microtubes and kept at $4^{\circ} \mathrm{C}$.

\section{Thermal treatment of spore suspension}

$\mathrm{D}$ values in citrate-phosphate buffer adjusted were determined at $95^{\circ} \mathrm{C}$ with one replicate at each $\mathrm{pH}$ ranging from 5 to 7.

First, $30 \mu \mathrm{l}$ of spore suspension was diluted in $3 \mathrm{ml}$ buffer. Capillary tubes of 25 $\mu \mathrm{l}$ (vitrex) were filled with $10 \mu \mathrm{l}$ of sample and submitted to a thermal treatment in a thermostated oil bath. After heating, the tubes were cooled in water/ice bath, washed in a solution of soap and rinsed with sterile distilled water. Finally, the ends were flamed with ethanol. The capillary tubes were broken at both ends and their contents poured into a tube containing $9 \mathrm{ml}$ sterile tryptone salt broth (Biokar Diagnostics) by rinsing with $1 \mathrm{ml}$ tryptone salt broth contained in a needle-equipped syringe.

\section{Recovery conditions}

Viable spores were counted by duplicate plating in nutritive agar $(10 \mathrm{~g}$ tryptone, $5 \mathrm{~g}$ meat extract, $5 \mathrm{~g}$ sodium chloride, $15 \mathrm{~g}$ agar for $1000 \mathrm{ml}$ water)(Biokar Diagnostic) and incubated at $25^{\circ} \mathrm{C}$ for 6 days. The $\mathrm{pH}$ medium 
ranging from 5 to 7 was adjusted with $\mathrm{H}_{2} \mathrm{SO}_{4} 1 \mathrm{~N}$ before autoclaving. After autoclaving the $\mathrm{pH}$ was measured and the final $\mathrm{pH}$ value was kept for calculations.

For media whose $\mathrm{pH}$ was lower than $5.5,10 \mathrm{~g} / \mathrm{l}$ of agar was added. A solution of $\mathrm{Na}_{2} \mathrm{SO}_{4}$ was added to adjust the medium at the same ionic strength.

\section{Data analysis}

$\mathrm{D}$ values were based on the reciprocal of slopes obtained when the log number of survivors was plotted against time.

Parameters of the models were fitted by simple or multiple linear regressions carried out with the STAT-ITCF software (Institut Technique du Fourrage France).

The goodness of fit of the model was evaluated by using the accounted for per cent variance (Snedecor and Cochran, 1969) which is given by:

$$
R^{2}=1-\frac{\left(1-r^{2}\right)(n-1)}{(n-N-1)}
$$

where $\mathrm{n}$ is the number of observations, $\mathrm{N}$ the number of terms and $\mathrm{r}^{2}$ is the multiple regression coefficient. Complementarily, mean square errors were determined.

\section{Results}


In a first set of experiments spores were heated at $95^{\circ} \mathrm{C}$ in media ranging from pH 5 to 7 and recovered at $25^{\circ} \mathrm{C}$, at the optimum recovery $\mathrm{pH}(6.7)$. Observed D-values are shown in table $1 . \log \mathrm{D}$ values were then plotted $v s\left(\mathrm{pH}^{\mathrm{p}} \mathrm{pH}^{*}\right)^{2}$ (fig1). The $\mathrm{pH}$ of maximal thermal resistance related to the studied strain of $B$. cereus was close to 7.5 (Gaillard et al., 1998). The model was then fitted with $\mathrm{pH}^{*}=7.5$ according to a linear regression (table 2).

In a second set of experiments, spores were heated at $95^{\circ} \mathrm{C}$ in a medium of $\mathrm{pH} 7$ and recovered at $25^{\circ} \mathrm{C}$ in media ranging from $\mathrm{pH} 5$ to 7 . Observed apparent decimal reduction times are shown in table $3 . \log \mathrm{D}^{\prime}$ values were then plotted $v s$ $\left(\mathrm{pH}^{\prime}-\mathrm{pH}^{\prime *}\right)$ with $\mathrm{pH}^{\prime *}=6.7$. Fitted parameters according to the linear regression are presented in table 4 . The observed satisfactory goodness of fit allows to adopt the same function for the destruction factor as for the stress factor (Eqn 5 and 6 respectively).

As foods make up the heating menstruum and the recovery medium, a third set of experiments, in which spores were recovered at the same $\mathrm{pH}$ as those of the heating menstruum, was carried out in order to validate the overall model. Parameters of the overall model were not fitted but parameters'values obtained from the first two independent sets of data (tables 2 and 4) were used in order to compute D' values. Squares on Figure 3 represent observed $\log D^{\prime}$ values while the continuous line corresponds to the calculated values according to the model. 
The correlation between observed and calculated values gives a $\mathrm{R}^{2}$ value of 0.968 and a Mean Square Error of 8.83.10-3.

\section{Discussion}

Currently the D-values used to establish sterilisation process were not taken into account in the recovery phase. The overall model (Eqn 7) is proving to describe successfully the influence of the $\mathrm{pH}$ on the heat resistance of spores both during the heat treatment and the recovery phase. However its lack of robustness, due to overparameterization, makes it difficult for it to be used for calculating heat food processes. Lack of robustness is pointed out by the following test: if instead of calculating D' values with parameters separately estimated from the first two independent sets of data, parameters are fitted according to the actual observed D' values from the third set of data $\left(\mathrm{pH}^{*}\right.$ and $\mathrm{pH}^{\prime *}$ are then held to be fitted parameters and not fixed values), quite different values are obtained from those previously determined (table 5). On account of the great variability of microbial species and strains, it seems worthwhile, in the framework of standard calculations, to fix $\mathrm{pH}^{*}$ and $\mathrm{pH}^{*}$ values to 7.Consequently, when $\mathrm{pH}^{\prime}=\mathrm{pH}$, Eqn (7) is reduced to

$$
\begin{aligned}
& \log D^{\prime}=\log D^{*}-\left(\frac{1}{z_{p H}^{2}}+\frac{1}{z_{p H}^{\prime 2}}\right)\left(p H-p H^{*}\right)^{2} \\
& \log D^{\prime}=\log D^{*}-\frac{1}{Z_{p H}^{2}}\left(p H-p H^{*}\right)^{2}
\end{aligned}
$$


Fitted parameters of this simplified model are respectively $D^{*}=2.27 \mathrm{~min}$ and $\mathrm{Z}_{\mathrm{pH}}=1.69$, with $\mathrm{R}^{2}=0.976$ and a Mean Square Error of $4.34 .10^{-3}$. The robustness of the new overall parameter $\mathrm{Z}_{\mathrm{pH}}$ was checked through the following test: $\mathrm{z}_{\mathrm{pH}}$ and $\mathrm{z}_{\mathrm{pH}}^{\prime}$ were fitted again while standard values were affected to $\mathrm{pH}^{*}$ and $\mathrm{pH}^{\prime *}$ (7 instead of 7.5 and 6.7 respectively). As expected, new values were clearly different from previous ones $\left(\mathrm{z}_{\mathrm{pH}}=2.62\right.$ instead of 3.10 and $\mathrm{z}_{\mathrm{pH}}^{\prime}=2.04$ instead of 1.75). However, when calculating the overall $\mathrm{Z}_{\mathrm{pH}}$ value from the following relationship

$\frac{1}{Z_{p H}^{2}}=\frac{1}{z_{p H}^{2}}+\frac{1}{z_{p H}^{\prime 2}}$

$\mathrm{Z}_{\mathrm{pH}}=1.61$ was found, which is close to the value determined from the last set of data.

It is clear that substituting model $(7)\left(5\right.$ parameters when $\mathrm{pH}^{*}$ and $\mathrm{pH}^{*}$ are fitted instead of being fixed ) for the more parsimonious model (9) ( only 2 parameters) is likely to lead to some lost of goodness of fit : a $\mathrm{R}^{2}$ value of 0.976 instead of 0.983 and a Mean Square Error of 4.34.10-3 instead of 2.99.10-3 are obtained. However, this drawback is largely set off by the simplification and the improvement of the model's robustness.

When a $\mathrm{n}$ decimal reduction ratio is aimed, at the reference temperature $\left(121.1^{\circ} \mathrm{C}\right)$ and at $\mathrm{pH} 7$, the sterilisation value must be:

$\mathrm{F}=\mathrm{nD}^{*}{ }_{121.1^{\circ} \mathrm{C}}$ 
At $121.1^{\circ} \mathrm{C}$ but at a $\mathrm{pH}$ different from 7 , the time of heat treatment leading to the same destruction ratio will be:

$\mathrm{t}=\mathrm{nD}^{\prime}{ }_{121.1^{\circ} \mathrm{C}}$

Combining Eqn (11) and (12) gives:

$$
\begin{gathered}
F=\frac{D^{*}{ }_{121.1^{\circ} \mathrm{C}}}{D^{\prime}{ }_{121.10^{\circ} \mathrm{C}}} t=L_{121.1^{\circ} \mathrm{C}}(p H) t \\
L_{121.1^{\circ} \mathrm{C}}(p H)=10^{\frac{\left(p H-p H^{*}\right)^{2}}{Z_{p H}^{2}}}
\end{gathered}
$$

The function $\mathrm{L}(\mathrm{pH})$ must be regarded as a partial apparent Biological Destruction Value (partial because $\mathrm{pH}$ is here the only considered factor).

Obviously, the studied strain of $\underline{B . c e r e u s}$ which is very sensitive to recovery medium $\mathrm{pH}$, is not a representative strain likely to be used as an indicator strain in order to develop standard heat process calculations. From data of Lopez et al., (1996), it was possible to fit $\mathrm{z}_{\mathrm{pH}}$ values of 4 strains of Bacillus stearothermophilus which were heated at $120^{\circ} \mathrm{C}$. Another set of data from the same laboratory (Lopez et al., 1997) allowed to fit $\mathrm{z}_{\mathrm{pH}}^{\prime}$ values related to the same strains. For each strain, overall $\mathrm{Z}_{\mathrm{pH}}$ values were deduced from Eqn (10), (see Table 6). Table 7 shows the magnitude of partial apparent Biological Destruction Values related to $\underline{B}$. stearothermophilus with an average $\mathrm{Z}_{\mathrm{pH}}$ value of 3.4. Further works would be needed in order to validate the model more generally and to determine $\mathrm{Z}_{\mathrm{pH}}$ value related to other representative species, especially $\underline{\text { Clostridium botulinum. }}$. 


\section{References}

Aderton, G., Ito, K.A.and Chen, J.K. 1976. Chemical manipulation of the heat resistance of Clostridium botulinum spores. Appl. Envron. Microbiol. $31,492-$ 498.

Cook, A.M. and Brown, M.R. 1965. Relationship between heat activation and percentage colony formation for Bacillus stearothermophilus spores: effects of storage and $\mathrm{pH}$ on the recovery medium. J. Appl. Bacteriol. $28,361-364$.

Cook, A.M. and Gilbert, R.J. 1968. Factors affecting the heat resistance of Bacillus stearothermophilus spores. I. The effect of recovery conditions on colony count of unheated and heated spores. J. Food Technol. 3 ,285-293.

Davey, K.R., Lin, S.H. and Wood, D.G. 1978. The effect of pH on continuous high temperature/short time sterilisation of liquids. Am. Inst. Chem. Eng. J. 24 ,537-540.

Gaillard, S., Leguérinel, I. and Mafart, P. 1998. Modelling combined effects of temperature and $\mathrm{pH}$ on heat resistance of spores of $\underline{\text { Bacillus cereus. (in press). }}$

Jordan, R. and Jacobs, S. 1948. Studies in the dynamics of desinfection. XIV. The variation of the concentration exponent for hydrogen and hydroxyl ions with the mortality level using standard cultures of Bact. coli at $51^{\circ} \mathrm{C}$. J. Hyg. 46 ,289-295. 
Lopez, M., Gonzalez, I., Condon, S. and Bernardo, A. 1996. Effect of pH heating medium on the thermal resistance of Bacillus stearothermophilus spores. Int. J. Food Microbiol. 28 ,405-410.

Lopez, M., Gonzalez, I., Mazas, M., Gonzalez, J., Martin,R. and Bernardo,A. 1997. Int. J. Food Sci. Technol. 32 ,305-311.

Mafart, P. and Leguérinel, I. 1998. Modelling combined effects of temperature and $\mathrm{pH}$ on heat resistance of spores by a linear-Bigelow equation. J. Food Sci. $63,6-8$.

Mallidis, C.G. and Scholefield, J. 1986. Evaluation of recovery media for heated spores of Bacillus stearothermophilus . J. Appl. Bacteriol. 61 ,517-523. Santos, M.H. and Zarzo, J.T. 1996. Evaluation of citric acid and GDL in the recovery at different $\mathrm{pH}$ levels of Clostridium sporogenes PA3679 spores subjected to HTST treatment conditions. Int. J. Food Microbiol. 29 ,241-254. Townsend, C.T., Esty, J.R. and Baselt, F.C. 1938. Heat resistance studies on spores of putrefactive anaerobes in relation to determination of safe processes for canned foods. Food Res. 3 ,323-346.

Tsuji,K., El-Bisi, H.M. and Esselsen, W.B. 1960. Thermal resistance of Clostridium sporogenes (P.A. 3679)at the intermediate pH range. Food Technol. 14,47 .

Yokoya, F. and York, G.K. 1965. Effect of several environmental conditions on the thermal death rate of endospores of aerobic, thermophilic bacteria. Appl. Microbiol. 13 ,993-999. 


\section{Abstract}

A simple overall model was proposed to describe the effect of both $\mathrm{pH}$ of the heating menstruum and $\mathrm{pH}$ of the recovery medium on apparent spore heat resistance of Bacillus cereus. Applied to foods making up both heating and recovery media, the model can be reduced to only 2 parameters. Its goodness of fit and its robustness enable it to be applied for the optimisation of heat treatments. However, further experiments should be undertaken to validate the model for other species and to determine parameters related to reference species such as $\underline{\text { Clostridium botulinum. }}$

KEYWORDS: $\mathrm{pH}$, heat resistance, recovery, Bacillus cereus. 


\section{Legends of tables}

Table 1. The effect of the heating medium $\mathrm{pH}$ on the heat resistance of Bacillus cereus spores. $\mathrm{D}_{95}(\mathrm{~min})$

Table 2. Rate coefficient related to equation $5\left(\mathrm{pH}^{*}=7.5\right)$

Table 3. The effect of the recovery medium $\mathrm{pH}$ on the apparent heat resistance of Bacillus cereus spores. $\mathrm{D}_{95}^{\prime}(\mathrm{min})$

Table 4. Rate coefficient related to equation $6\left(\mathrm{pH}^{\prime *}=6.7\right)$

Table 5. Rate coefficient related to equation 7

Table 6. $\mathrm{z}_{\mathrm{pH}}, \mathrm{z}_{\mathrm{pH}}^{\prime}$ and $\mathrm{Z}_{\mathrm{pH}}$ values related to Bacillus stearothermophilus , according to Lopez et al.'s data $(1996,1997)$

Table 7. Partial apparent Biological Destruction Values vs medium $\mathrm{pH}$ with $\mathrm{Z}_{\mathrm{pH}}=3.4$ 


\section{Legends of figures}

Fig. 1. Fitting of $\log \mathrm{D} v s\left(\mathrm{pH}-\mathrm{pH}^{*}\right)^{2}$ with $\mathrm{pH}^{*}=7.5$

Fig 2. Fitting of $\log \mathrm{D}^{\prime} v s\left(\mathrm{pH}^{\prime}-\mathrm{pH}^{\prime *}\right)^{2}$ with $\mathrm{pH}^{\prime *}=6.7$

Fig 3. Observed (squares) and calculated (continuous line) D' values according to equation 7 and parameters values indicated in Tables 2 and 4. 
Table 1.

\begin{tabular}{|c|c|}
\hline $\mathrm{pH}$ & $\mathrm{D}_{9{ }^{\circ} \mathrm{C}}(\mathrm{min})$ \\
\hline 5 & 0.64 \\
5.25 & 0.79 \\
& 0.76 \\
5.5 & 0.98 \\
& 1.10 \\
6 & 1.71 \\
& 1.62 \\
6.5 & 1.91 \\
& 2.07 \\
7 & 2.52 \\
& \\
& \\
& \\
& \\
& \\
\end{tabular}


Table 2.

\begin{tabular}{|c|c|}
\hline Number of data & 11 \\
\hline $\mathrm{R}^{2}$ & 0.981 \\
Mean Square Error & $6.78 .10^{-4}$ \\
$\mathrm{D}_{95^{\circ} \mathrm{C}^{*}}$ & $2.71 \mathrm{~min}$ \\
$\mathrm{z}_{\mathrm{pH}}$ & 3.10 \\
\hline
\end{tabular}


Table 3.

\begin{tabular}{|c|c|}
\hline $\mathrm{pH}^{\prime}$ & $\mathrm{D}_{95{ }^{\circ} \mathrm{C}^{\prime}}(\mathrm{min})$ \\
\hline 5 & 0.33 \\
5.15 & 0.26 \\
5.25 & 0.42 \\
5.5 & 1.22 \\
5.8 & 1.65 \\
5.9 & 1.81 \\
5.95 & 1.72 \\
6.2 & 1.58 \\
6.35 & 1.93 \\
6.35 & 2.27 \\
6.7 & 2.13 \\
6.75 & 2.17 \\
6.9 & \\
\hline
\end{tabular}


Table 4.

\begin{tabular}{|c|c|}
\hline Number of data & 13 \\
$\mathrm{R}^{2}$ & 0.942 \\
Mean Square Error & $5.77 .10^{-3}$ \\
$\mathrm{D}_{95^{\circ} \mathrm{C}}$ & $2.17 \mathrm{~min}$ \\
$\mathrm{z}_{\mathrm{pH}}^{\prime}$ & 1.74 \\
\hline
\end{tabular}


Table 5.

\begin{tabular}{|c|c|}
\hline Number of data & 20 \\
\hline $\mathrm{R}^{2}$ & 0.983 \\
\hline Mean Square Error & $2.99 .10^{-3}$ \\
\hline $\mathrm{pH}^{*}$ & 7.87 \\
\hline $\mathrm{pH}^{\prime *}$ & 7.38 \\
\hline $\mathrm{D}_{95^{\circ}} \mathrm{C}^{*}$ & 3.36 min \\
\hline $\mathrm{z}_{\mathrm{pH}}$ & 3.59 \\
\hline $\mathrm{z}_{\mathrm{pH}}^{\prime}$ & 2.53 \\
\hline
\end{tabular}


Table 6.

\begin{tabular}{|c|c|c|c|}
\hline Strain & $\mathrm{Z}_{\mathrm{pH}}$ & $\mathrm{z}_{\mathrm{pH}}^{\prime}$ & $\mathrm{Z}_{\mathrm{pH}}$ \\
12980 & 3.82 & 3.06 & 2.39 \\
7953 & 3.97 & 3.80 & 2.75 \\
15951 & 3.45 & 3.21 & 2.35 \\
15952 & 4.12 & 2.94 & 2.39 \\
\hline
\end{tabular}


Table 7.

\begin{tabular}{|c|c|}
\hline $\mathrm{pH}$ & $\mathrm{L}_{120^{\circ} \mathrm{C}}(\mathrm{pH})$ \\
\hline 7 & 1.00 \\
6.5 & 1.11 \\
6 & 1.49 \\
5.5 & 2.46 \\
5 & 4.95 \\
\hline
\end{tabular}


Figure 1

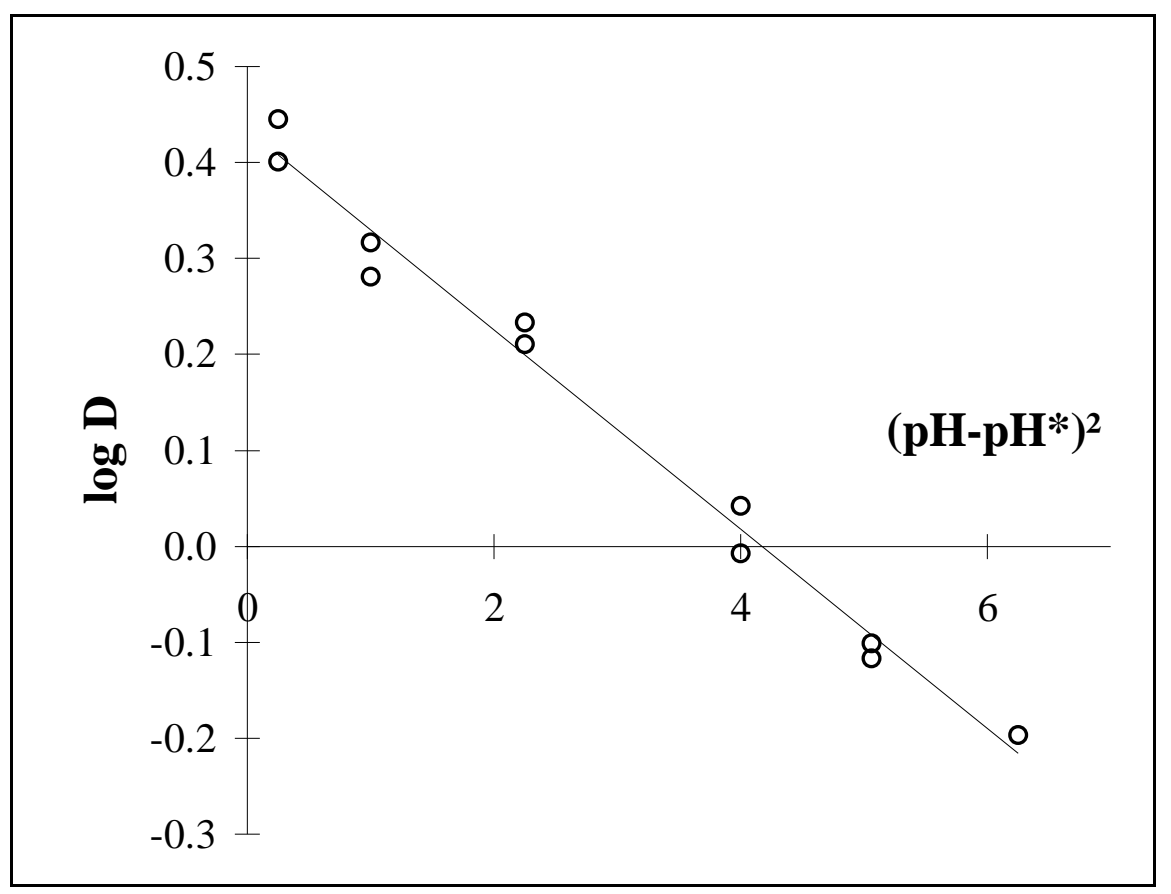


Figure 2

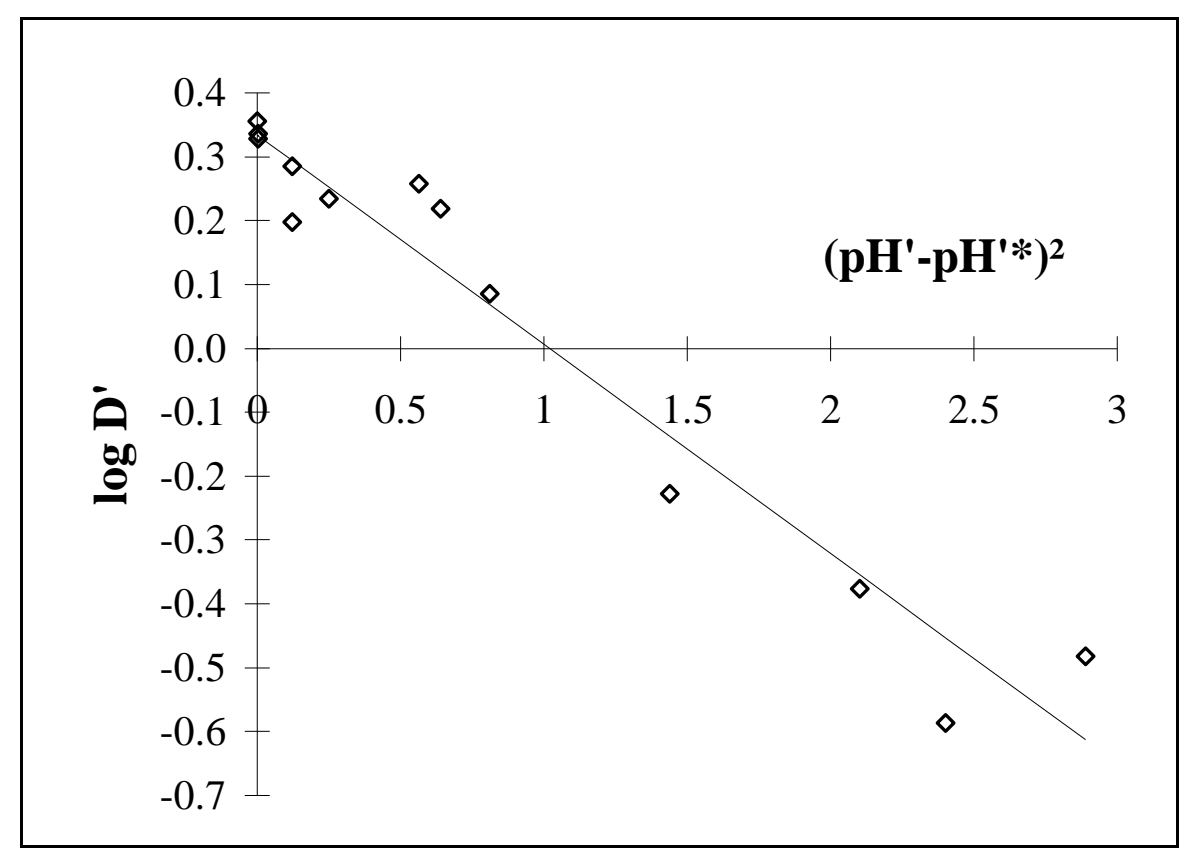


Figure 3

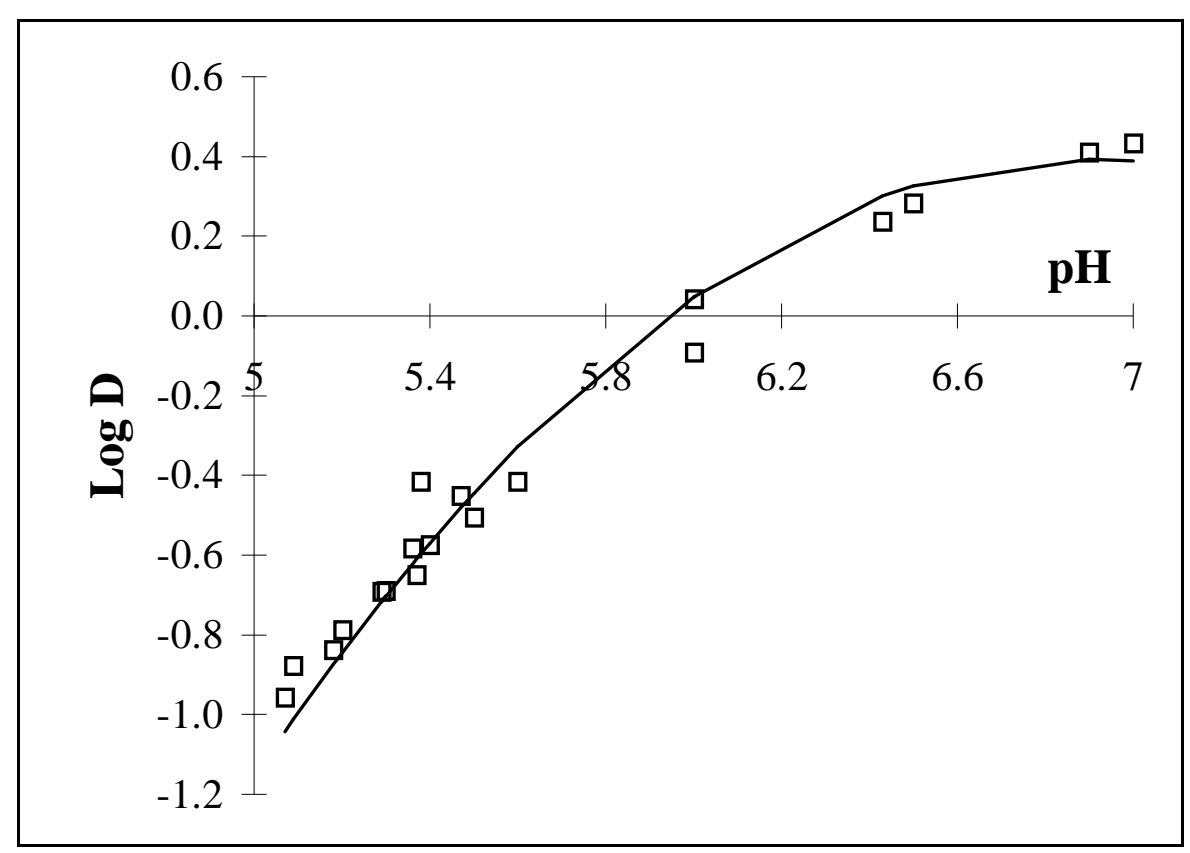

